\title{
CHAPTER
}

\section{7 \\ Discourse in Organizations and Workplaces}

\author{
Britt-Louise Gunnarsson
}

This chapter focuses on discourse in organizations and workplaces and will discuss a number of studies which explore the complexity and diversity of communication in modern working life. With a theoretical orientation towards sociology, organization/network theory and social constructivism, researchers have sketched the macro-frames which influence discourse at various levels within organizations. Studies of the correspondence between organizational structure and discourse will be used as a background for presentations of analyses which try to grasp and understand communication in the modern organization from different viewpoints and with a focus on different problem areas. The theoretical and methodological perspectives of these analyses include textlinguistics, ethnography, critical discourse analysis, interactional sociolinguistics and conversation analysis.

A relevant question for our understanding of modern working life is related to the effects of technological advance and globalization. The conditions for professional discourse have been influenced by a series of changes taking place in recent decades. Technological advances have facilitated a globalization of working life, while lifelong learning, flexibility, mobility and diversity have come to be key values in the global economy. In organizations throughout the world, we find a widespread use of technology and increased reliance on the internet for internal and external communication. Another striking feature, made possible of course by the technological advances, is the globalization of the business world and the job market. Throughout the world, we find transnational companies which use English as their corporate language and employ multilingual people who can move between jobs, between branches and between countries. The workforce mobility and workplace diversity which characterize a globalized economy also raise issues of multilingualism and multiculturalism to the surface, both in relation to the organization as a whole and to workplace practices. For employees this new situation has come to entail different and higher demands for literacy and communicative skills.

The purpose of this chapter is to deepen our understanding of the discourserelated problems facing managers and employees in the globalized economy. In the various sections of the chapter I discuss these problems from different viewpoints. First, I explore the correspondence between organizational structure and discourse at a more general level, where I use examples from analysis of small 
workplaces and large organizations. Secondly, I view organizational discourse from the point of view of the top-level management and discuss how an 'organizational self' is constructed by means of discourse, and the role of discourse for internal management and external marketing in the global economy. Thirdly, I view discourse from a workplace perspective to distinguish two types of multilingual workplaces: those which use English as lingua franca and the multilingual workplaces with a workforce diversity. Fourthly, I discuss workplace discourse in the 'new work order' with a particular focus on the consequences for the individual employee of technological advances and a globalized economy. Last, I will sketch some topics for future research.

\subsection{Organizational Structure and Discourse}

An important macro question, which is discussed here, concerns the correspondence between the organizational structure and discourse. This correspondence is seen here as a two-way relationship. Creating texts (written, spoken, and computer-mediated) therefore forms part, and an important part, of an organization's work. Texts ${ }^{1}$ are influenced by the social context, thus reflecting the organization and its social structure, values, knowledge and culture. But texts also play a part in establishing the various social dimensions of the organization. They are not only a product of the social situation, but in their turn also shape it. We could therefore distinguish the basic traits of a sociolinguistic order of discourse which appear in varied forms depending on the size and structure of the organization.

\subsubsection{The Sociolinguistic Order of Discourse in a Close-Knit Group}

The first study I discuss provides an example of the simple sociolinguistic order of discourse, which we find in close-knit workplace groups. Gunnarsson (1997) presents a study of text production in a local government office with 35 employees. The bulk of her data was collected by means of a survey given to all employees and in-depth interviews. This study also included an analysis of the flow of texts, i.e. all texts emanating from the office during a fixed period were categorized in relation to sender, addressee and purpose.

In this workplace there was an obvious connection between the social and the communicative plane. The group structure was reflected in the communicative structure: the hierarchical social structure was reflected in communicative patterns relating to influence and supervision; the informal group formation was reflected in informal joint writing efforts. The social organization at the office was reflected in the communicative organization: texts were produced as a collaborative effort; those involved in writing documents took a collective responsibility for the text and there was an obvious interaction between speech and writing. Another finding related to the interaction between social and communicative factors at the level of content. In the interviews, the employees expressed a strong feeling of group identity, a 'we feeling' that distinguished this particular group from employees in 
other local government offices. This group identity manifested itself in many ways, also in relation to writing. The interviewees made it plain that in this office they not only had the right to cultivate a distinctive style, they made full use of this right. They regarded themselves as pioneers of a more informal official idiom. One conclusion that can be drawn from this is that even small groups, such as a local government office with 35 employees, consider that they have the right to be innovative in their writing. The interviews also showed that language is an element in the build-up of the social group identity and culture. At this workplace, there was thus a two-way relationship between discourse and the organization, i.e. texts and discourse reflected the social organizational patterns but also played their part in the construction of the 'organizational self', in the shaping of the organization.

\subsubsection{The Multilayered Structure of Discourse in Large Organizations}

Looking at communication within large organizations leads, of course, to a complex and multi-dimensional picture of the correspondence between organizational structure and discourse. Large organizations function within various social frameworks with different hierarchical structures, different values, different knowledge and different culture, and various sociolinguistic orders of discourse overlap and intertwine leading to a complex and multilayered structure of discourse. In order to understand communication in large organizations we must therefore consider the interaction between different levels: the local environment, the organization, the relevant local sector, the national sector, the national linguistic community, the sector worldwide.

In Gunnarsson (2004a, b), this model is used for analyses of communication in large, mainly national, European organizations. The results discussed are taken from analyses within the research project entitled Texts in European Writing Communi$t_{i e s^{2}}$, which studied texts and text production in four mainly national writing communities - banks, structural engineering firms, university occupational medicine departments and university departments of history - in three countries: Sweden, Germany and Britain. One purpose of the project was contrastive, i.e. a comparison of Swedish, German and English texts of similar kinds were made; another was sociolinguistic, which involved studying the relationship between national culture, organization and texts. The study comprised interviews, collecting texts, corpus construction and textual analysis. Altogether, 70 executives and employees, responsible for or involved in information activities and the production of texts, were interviewed. The team also collected samples of the types of texts produced in the environment concerned, which were then used to form the basis of a corpus containing text types that occurred in several environments. In total the corpus consisted of 15 different text types, e.g. annual reports, brochures, letters, press releases, reports, staff magazines. The textual analysis was multifaceted, comprising analysis at the cognitive, pragmatic and macrothematic levels of the texts as well as analysis of argumentation, discourse markers and images and image creation in companies.

The results of the analyses of the interviews and the collected texts reveal interesting differences between the sectors - between banks and structural engineering 
companies as well as between occupational medicine and history departments and also between texts produced in different national writing communities: Germany, Sweden and Great Britain. Another finding of interest is the homogeneity within each organization. A fairly homogeneous picture could be drawn of each company, both based on the analyses of its texts and on interview data. To a certain extent this homogeneity could be related to the ideas steering each organization. In particular this became striking in relation to the banks in the study, which were guided by different ideas about organizational structure (hierarchical or flat organization) and marketing (strong belief in advertising or in individual interaction, i.e. service management). Part of the variation found in text patterns between the texts from the banks could also be related to this variation in ideas. Though the degree of importance of the national culture and the international community may vary from one enterprise to the other, the multilayered structure can be assumed to be fairly similar. In national as well as international enterprises, the simple sociolinguistic order of individuals forming a close-knit group is intertwined with various levels of other orders leading to a multifaceted and multilayered disorder.

\subsection{The Construction and Maintenance of an 'Organizational Self'}

From the point of view of the top management of large - national and international - organizations, one problem area is related to the creation of external and internal images of the organization which can be accepted in various local settings, another is how to create a coherent organization working for the same visions. Texts, spoken discourse and computer-mediated communication are very important in the creation of an 'organizational self' and also for the presentation of the organization as an attractive unit in the eyes and ears of those outside and inside it.

\subsubsection{Internal Management and Marketing}

Modern management theory talks about the need for internal marketing, e.g. as a means of creating and controlling the organizational culture (Peters and Waterman, 1982), and most top managers are fully aware of this. Discourse is at the heart of this internal construction of the company as a unique and attractive entity, and most organizations attach great importance to news dissemination and storytelling within the organization. Stories of success and failure are told and retold in organizations, thus disseminating knowledge of the behavioural patterns to be followed or avoided in the future (Linde, 1999). In the internet era, they are also found on the companies' websites. Not only stories of the company and its history, but also of individual employees and successful customers are found on various sub-pages (Gunnarsson, 2008). Although their explicit goals vary, these stories all help construct an 'organizational self' intended not only to attract new customers, owners and prospective employees but also to help maintain the existing organizational culture. 
In modern organizations, the top managers devote a great deal of time to creating mission statements and organizational visions (Swales and Rogers, 1995; Isaksson, 2005). A problem, however, is that a top-down communicative strategy does not always mean that the same message penetrates the whole organization, and organizational visions are not infrequently interpreted by employees as unintelligible and insignificant. Johansson (2003) presents a case study which tries to probe this problem. Using a combination of methods, including participant observation, discourse analysis and interviews, she analysed the organizational communication about strategy in a Finnish-Swedish enterprise. Communication about the strategy followed a typical top-down model, starting at group level and ending on department level. She found that visions formulated by top managers met different realities constructed by managers at lower levels in the company. Managers' attitudes, knowledge and interpretations were important individual factors that influenced communication about the strategy. Employees did not have the same detailed knowledge of the strategy as the managers, nor were they given the same opportunities to acquire it. Power structures, conflicts, individual attitudes and perspectives contributed to the successive distortion of the top management's visions. Johansson's study is interesting as an attempt to grasp the whole process.

\subsubsection{External Communication and Marketing}

The role of discourse is no less obvious in relation to the construction of an externally addressed image which promotes success and growth. It is obvious that many enterprises have succeeded in spreading a uniform image of themselves which is accepted in a variety of countries and cultures. Logos, advertisements, shop design, stories contribute to this uniformity as well as the products as such. In some cases, the national origin of the company has come to be an essential part of its image and the construction of uniformity. A well-known symbol for American culture is McDonalds with its branches all over the world. Uniformity at every level from the product to the design of its restaurants - characterizes this franchising company. In many countries, however, the image of McDonalds has come to be seen as representing the negative aspects of American culture at the same time as the company sells its hamburgers. A less ambiguous connection between national culture and corporate image has been created by IKEA. Swedishness has become one element in IKEA's trademark, and it has obviously managed to turn Swedishness into an image that sells. The company's products are given Swedish personal names, like Bosse, Björn etc. One goal in its naming policy is to present an image of 'trygghet' (familiarity and security) to the Swedish audience, and an image of a Nordic product to the international audience. Names with the Swedish letters $a, \ddot{a}$ and $\ddot{o}$ are therefore not avoided, but in fact deliberately used to strengthen IKEA's exotic image. ${ }^{3}$ The ways in which customers are addressed are also aimed at strengthening the sense of Swedishness. In countries like Austria, e.g., employees address customers in speech and writing using 'du' instead of the normal 'Sie'. 
As part of its Swedish image, in other words, IKEA wishes to introduce the more egalitarian and familiar language and forms of address that have been used in Sweden since the second person pronoun reform in the 1960s (cf. Gunnarsson, 2001).

Other companies have been successful in using strategies that permit greater cultural variation. An interesting model for text production is described in Jämtelid (2001, 2002). The concept of 'parallel writing' is used for the analysis of the multilingual production of text in the Electrolux corporate group, where English is the official language (cf. Gunnarsson and Jämtelid, 1999). This investigation, which is based on interviews and text analysis, reveals an interesting model for the balance between the local and the global. To provide a basis for company texts, e.g. brochures for vacuum cleaners, a textual base in English is devised at the main office in Stockholm, Sweden, and circulated to the sales companies in the other countries. The textual base then provides the raw material for the various consumer brochures produced in different languages and intended for different cultures. As Jämtelid's analyses show, the different sales companies have chosen to incorporate different ideas from the textual base circulated by head office. She also found marked differences in the arguments for the product presented in the brochures, the choice of illustrations and the styles used. There were thus clear differences between Electrolux brochures written in different countries about the same vacuum cleaner and based on the same original. The differences found between the texts of the brochure in the various countries could indicate culturally derived differences (Jämtelid, 2002).

This text production strategy, which was established by the Electrolux group in the 1990s for the production of printed brochures, is interesting as it combines the need for top-down control and group unity with the need for local and national variation. In addition, it allowes for both linguistic and cultural variety.

In the modern technological business world, computer-mediated texts are, to a large extent, replacing printed texts for external purposes. Products are marketed on the companies' websites and emails are replacing letters on paper. One important difference between texts on a company's website and printed documents is their accessibility. When a company places a text on its website, it has to count on multiple readerships. Global accessibility is a reality for texts on websites. The specified reader of the printed document is replaced by a potentially manifold readership: shareholders, staff, journalists, politicians, former and prospective customers in countries all over the world can view the company website. Although the company can, in theory, count on multiple readerships for the texts on its website, it does not mean that the actual number of readers increases, nor any rise in the number of individuals who feel themselves directly addressed by the company's texts. The language used on a sub-page includes or excludes reader groups as does the cultural perspective and focus of the actual text.

One consequence of the increased reliance on the internet is that company policy on linguistic and cultural issues becomes salient and visible for different reader groups. From a critical analysis viewpoint, the company's textual practices on its websites reveal, among other things, its interpretation of the concept of diversity - a key term in the modern business world. The languages used on the 
company's customer-oriented pages reveal the groups of readers to which they wish to sell their products, and also those that they make no effort to approach. Are the English speaking elite among the intended readers? Do the majority language speakers in a country belong to the intended readers? Are immigrants and other minority language speakers in a country also addressed in a language they fully understand?

Gunnarsson (2006) presents a study of the language practices of the websites maintained by five transnational companies: ABB, Astra Zeneca, Electrolux, Ericsson and Scania. All these companies claim to be world leaders in their fields: ABB is a leader in power and automation technologies that enable utilities and industrial customers to improve performance while reducing environmental impact. Astra Zeneca is one of the world's leading pharmaceutical companies, Electrolux is the world's largest producer of appliances and equipment for kitchens, cleaning and outdoor use, Ericsson is the biggest supplier of mobile telephone systems in the world and supports all major standards for wireless communication, and Scania is one of the world's leading manufacturers of heavy trucks and buses.

In this study, which was carried out in September 2005, the focus was on the customer-oriented websites, i.e. the companies'.com-sites. All the companies have a .com-site in English, functioning as a start page. For all five companies, we also find the option of selecting a country on the start page. The number of country links varies among the five companies, which of course reflects the global reach of each group: ABB has 112 country links on its webpage, Astra Zeneca 105, Electrolux 67, Ericsson 111 and Scania 39 links. The interest here relates to the language practices of the country websites. In which language(s) do the five companies present themselves and their products to customers in different regions of the world. Nine of the country links, namely those for Sweden, Finland, Norway, Germany, Switzerland, France, Spain, Brazil and Japan, were analysed.

Among other things, this analysis reveals that all five companies use the main language of the country to address customers, e.g. Norwegian on the website for Norway, Portuguese on the website of Brazil and German on the site for Germany. Nevertheless, there is a noteworthy difference between companies which address their customers only in the main local language, and those that use both that language and English. There is also a difference among the companies that offer language options for countries with several official languages, e.g. both Finnish and Swedish in Finland, and both German, French, Italian and Rhaeto-Romance in Switzerland. However, only one of the companies, Scania, offers a choice between Finnish and Swedish for Finland, and only three, Scania, Electrolux and Astra Zeneca, a choice of both German and French for Switzerland.

There are sub-pages in English on all of Ericsson's country websites. All the ABB websites use the main national language, but for five countries, namely Sweden, Finland, Switzerland, Spain and Brazil, there is a language-choice button offering English as a second option. On the country websites of Astra Zeneca, Electrolux and Scania, on the other hand, we only find the national language(s). On two of Scania's sites there is a language-choice button that offers two national languages, and on one of the sites for Electrolux and AstraZeneca there is a similar button. 
None of the companies, however, provide any information in any immigrant language. As we know, there are large groups in many of these countries, who have a different mother tongue from the main national language. If we take Sweden as an example of the current language situation, statistics show that 11 per cent of the Swedish population and 22 per cent of the workforce (persons aged between 18 and 64) were not born in Sweden (cf. Gunnarsson, 2005). These figures might be even larger for other countries.

In theory, the internet offers global accessibility. In order to reach out to different reader groups, however, the company has to consider regional variation. The language used on a sub-page includes or excludes reader groups as does the cultural perspective chosen for the text. The balance between local and global concerns is thus related to policy and practice on linguistic and cultural matters. For the five companies studied, accessibility seems to be reserved for those prospective customers who either speak the main language of the country or have mastered English. The companies' claims to be global and international and to respect the value of diversity do not entail an interest in the mother tongues of the minorities within the different countries.

\subsection{The Multilingual Workplace}

The correspondence between organizational structure and discourse (cf. section 7.1) gets even more complex in large, global organizations where language and culture also become socially relevant issues. Although the multilingual workplace is not a new phenomenon, the growing workforce mobility in today's economy entails workplace diversity of a varied and somewhat new kind. Issues of multilingualism and multiculturalism are brought up to the surface, as are issues of dominance and marginalization. In this section of the chapter, I dwell on problem areas related to two kinds of multilingual workplaces. First, I will discuss studies of multilingualism in large corporations which use English as their lingua franca. Secondly, I will discuss studies of workplaces which focus on the diversity issue at a more local level.

\subsubsection{Multilingual Workplaces with English as Their Lingua Franca}

Globalized economy means that transnational organizations, i.e. organizations which operate in countries with different languages, need to choose one language as their lingua franca. Not seldom, at least in Europe, English is chosen as the lingua franca of these organizations. In countries where English is not the mother tongue, this creates different communicative problems, in relation to both outgoing and internal communication.

A number of recent studies have analysed communication with English as the lingua franca in large, European, organizations and also focused on the various problems related to this practice ${ }^{4}$. I will here discuss some studies which view the problem from a Scandinavian perspective. For all the Scandinavian countries, English has come to be the natural choice of a lingua franca at an international 
level: Swedish, Danish, Norwegian and Finnish are not understood outside Scandinavia, which indeed necessitates a lingua franca in external communication. In the past decade, English has also come to be used as a lingua franca in Nordic mergers, e.g. in the Finnish-Swedish company Stora-Enso. Kankaanranta (2005a: 42) describes the communicative practices within this company in the following way:

In practice, this language choice means that corporate-level documentation and all reporting is done in English, and communication between different units is mostly in English. This type of communication can be characterized as internal communication as it is taking place 'in-house' in contrast to communication between buyers and sellers in which foreign languages have been traditionally needed in international business. For an individual writer of an email message, the choice is a pragmatic one: anytime there are recipients whose mother tongue is not that of the writer's, the message is in English. This means that a Swede (or a Finn) will receive an English message from another Swede (or a Finn) if the list of recipients includes non-Swedish speakers.

The use of English as a corporate language has also impact on the recruitment of the workforce. Gunnarsson (2009b) presents an analysis of job advertisements on the career-oriented web pages of five transnational enterprises: ABB, AstraZeneca, Electrolux, Ericsson and Scania. All these enterprises are large employers in Sweden, and her study focused on advertisements for jobs in Sweden. She studied the Swedish website of these enterprises, i.e. www.abb.se, www. astrazeneca.se etc. For each job advertisement, she noted (1) in which language the advertisement was written, and (2) what languages were explicitly mentioned as qualifications for the job: Swedish, English or any other language(s). This study covered all jobs advertised on these websites in September 2005.

As regards the first issue, 63 per cent of the advertisements were written in Swedish, 32 per cent in English and 5 per cent in both Swedish and English. Broken down by company, the analysis shows that all advertisements for Ericsson are in English, while for Scania they are all in Swedish. ABB's adverts, too, are mainly in Swedish, while AstraZeneca has roughly similar proportions of Swedish and English advertisements. Electrolux also uses both languages to advertise jobs at Swedish workplaces. In fact, there are five advertisements that mix Swedish and English, i.e some parts of the text are in Swedish and some in English.

As regards the second issue, that is what language(s) are explicitly mentioned as requirements for the job, the results could be summarized in the following way: For the five transnational companies multilingualism means bilingualism, i.e. a knowledge of English and Swedish. Only 10 per cent of the advertisements mention languages other than Swedish and English as a qualification. English, on the other hand, is explicitly mentioned in 70 per cent of the advertisements. Swedish figures less prominently as a qualification, and is explicitly required in only 34 per cent of the adverts. 
Of course, the variation in terms of the qualifications required depends on the nature of the job. At a general level, however, we can say that multilingualism is mainly related to knowing English and to a lesser extent the main national language, in this case Swedish. The various other languages spoken in Sweden, e.g. Finnish, Persian, Arabic, are not mentioned at all. Of the immigrant languages, only Spanish, Russian and German are mentioned in the advertisements analysed.

From these descriptions of the language situation in large organizations in Sweden, I will turn to some studies which focus on the various problems related to the use of English as a lingua franca. When Jämtelid interviewed people involved in writing at different levels of the Swedish Electrolux group, she found that they themselves referred to their corporate English as 'bad English' (2002: 44). A widespread belief was that native speakers of English found their corporate English poor. The director of corporate communications, however, makes it clear that 'bad English' is not accepted in texts aimed at a wider readership. 'Although a presentation brochure obviously has to be correct, it still has to be possible to send a message or a letter or minutes to one another without them being a hundred per cent correct'. He also elaborates on the necessity for Scandinavians to speak up even if their English is bad:

Then of course the corporate language is quite clearly 'bad English'. Otherwise, you easily end up with only Americans, Brits and well-educated Swedes talking at meetings, while Germans and Italians remain silent. What happens, rather, is that we deliberately avoid difficult words, and that people shouldn't feel ashamed at all if they use bad grammar in an internal memo in English. (My translation.)

Another consequence relates to a levelling of cultural differences in favour of a more homogeneous style. In ongoing studies of Nordic mergers, the cultural issue has attracted attention. In her analysis of emails written in English by Swedish and Finnish employees of Stora Enso, Kankaanranta ${ }^{5}$ also looked at possible cultural differences. She was able to point to certain differences between the Swedish and Finnish writers:

In spite of the macro-level similarities, the messages written by Finns and Swedes also exhibited differences on the level of the moves, that is, the realization of the requests. Finns seem to favour direct requests in their writing, while Swedes use more indirect alternatives, thus supporting the notion of the more direct Finnish communication. (Kankaanranta, 2005a: 54.)

Nevertheless, her main conclusion relates to homogenization, in that her study suggests that 'lingua franca interactions are characterized by a high degree of cooperativeness and a consensual style; together the communicators aim at smoothness, and together they construct the situational meanings' (55). 
Other studies have been more negative about the levelling of cultural differences in international meetings. Fant (1992) on the basis of his analyses of crosscultural negotiations says that

If systematic longitudinal research had been carried out over the past, say, three or four decades in order to investigate the evolution of national patterns of doing business within what is commonly being referred to as the western world, the results would probably have indicated that, in the first place, things have changed a great deal globally, and, secondly, that national differences have diminished, yielding place to some sort of 'Americanized' style, which has served as a model to, and has reshaped, to a greater or lesser extent the local patterns. (Fant, 1992: 125.)

The same applies to Börestam (2005), who has analysed meetings within Nordea, another Nordic company with English as its official language. Her study covered meetings held in different countries (Denmark, Finland, Norway and Sweden) and in different languages. Her conclusion is that the levelling of cultural differences which for instance relate to the overall structure of the meeting discourse tends to favour a more Americanized style (71). Fant's and Börestam's conclusions can thus be seen as pointing to a more general problem involving the consequences for small languages and small national discourse communities of the dominance of English and the American culture (cf. Gunnarsson, 2001).

A third problem relates to the consequences of the divide between those with mastery of English and those without. In many organizations, the local language dominates the spoken discourse, while the more official documents are written in English. Language knowledge and language deficiencies are likely to create new hierarchies and social orders. New communicative problems become salient: Who can communicate with the top management? Who understands which texts? Who can perform which job within the organization? Who can communicate with whom in the workplace?

Johansson (2003) presents a case study of communication on corporate strategy within a transnational company with its head office in Sweden. She recorded and analysed the information flow relating to a strategy document produced at the top level of the company. The document was written in English and formulated by senior managers. Managers at lower levels were then supposed to present the contents to the employees. Johansson interviewed top and middle managers and also employees and recorded meetings at which the strategy document was presented and discussed. Her conclusion is that the visions formulated by top managers were transformed by the middle managers in accordance with their attitudes and conceptions of reality. The employees who acquired their information via the middle managers did not have the same detailed knowledge of the strategy as the managers, nor were they given the same opportunities to obtain it. Johansson's study shows, among other things, that the use of English for important internal documents might increase the distance between senior management and ordinary employees. 
In many cases, the divide between those with mastery of English and those without increases the gap between native and non-native speakers. The choice of English as a lingua franca in the Scandinavian context is quite natural from the perspective of those who grow up there. Everyone attending school in Sweden, for instance, is taught English as their first foreign language. People growing up in Sweden have also been exposed to English every day, as programmes on television (news, movies, comedies etc.) use Swedish subtitles and the original (mostly English) sound track. English is also used in much of the pop music produced and listened to in Sweden. The increased use of the internet has also meant that many Swedes daily read and write English for various purposes. A new type of 'elite bilingualism' is thus gradually developing in Sweden among young people and educated adults. For individuals who have moved to Sweden as adults, however, English is not always as easy as for those born in Sweden. Many immigrants have received their basic schooling (not uncommonly a very short one) in countries in the Middle East, Africa, Asia, South America and the former Eastern Europe, which means that they might not have been taught English at all, or at least not as their first foreign language. For them, the use of English as a lingua franca poses greater problems than for people who have received their basic education in Sweden. The foreign language they have to learn first, when moving to Sweden, is of course also Swedish and not English.

In organizations which use English as their official language these individuals' opportunities to advance are dependent on their acquisition of not only one foreign language, Swedish, but also English. Based on interviews with immigrant blue-collar and office workers employed in a Swedish transnational company ${ }^{6}$, Nelson gives this picture of the need for language knowledge at different levels:

To be able to get an office job with this company, you do not necessarily need to know that much Swedish, but you do need to at least understand English. On the factory floor, on the other hand, you would probably not only become lonely but also have problems if you did not speak Swedish. (Andersson and Nelson, 2005: 34.)

\subsubsection{Multilingual Workplaces with Workforce Diversity}

All over the world, there are workplaces where some employees, mostly minorities, immigrants or unskilled guest workers, have to use their second, third or fourth language at work. In many organizations, knowledge of the dominant local language is necessary not only for advancement and a career but also for social integration into the working group. Humour, jokes, stories, anecdotes form part of the workplace discourse and contribute to the establishment of friendship and collegiality at work and also to the avoidance of unnecessary conflicts. Social workplace patterns related to friendship, power and dominance often reflect linguistic and communicative skills ${ }^{7}$.

An ongoing Swedish research project focuses on the day-to-day communicative situation of immigrants employed in two different working environments: a major 
Swedish company and a large hospital. By means of interviews, observations and analyses of spoken and written discourse, the project team is studying how the immigrant's professional identity is constructed in the interaction with his/her fellow workers, and how discourse makes her/him an integrated part of the work team. With a methodological basis in interactional sociolinguistics, the attempt is to grasp the discourse strategies used by the immigrant and her/his colleagues to overcome communication problems and to establish a good working climate. A striking result is the communicative awareness of the immigrants; they are aware of their strength and weaknesses and have found ways to handle the various situations that occur during a workday. In the interviews they mention humour as a problem at work. Interestingly enough, however, the recordings show their ability to understand humour and also to tell jokes and stories themselves. Among other things, these studies reveal the collaborative character of workplace discourse. Language problems are overcome and humour and jokes are constructed in collaboration between the second language speakers and colleagues speaking their mother tongue. ${ }^{8}$

Though the link between workplace practice and organizational policy is not simple, the individual's social integration or marginalization could be assumed to be related to more structural issues, e.g. what is made central in various types of organizational discourse. From a critical perspective, it thus becomes relevant to analyse how the organization pictures its 'ideal' employees: Who is chosen to represent the organization? Who is chosen as a role model for new employees?

Gunnarsson (2008) focuses on this issue by means of an analysis of transnational companies' career-oriented web pages. All five companies studied - ABB, Astra Zeneca, Electrolux, Ericsson and Scania - have sub-pages presenting employees that are linked to their situations vacant pages. By means of this analysis, she can distinguish two groups among the companies. First, the international exchange made possible by their employment strategies is highlighted by three of the companies, namely ABB, Electrolux and Ericsson. ABB features ten Swedes who are or have been working abroad, while Electrolux, through its success stories, constructs a picture of a company that gives its employees, who should know several languages, an opportunity to work in many countries and meet people from other cultures. Ericsson, too, highlights the opportunity for international exchange, i.e. the company offers its employees the possibility of working abroad. In contrast to Electrolux, however, it makes no mention of employees' language skills.

Second, two of the companies, Astra Zeneca and Scania, highlight the diversity of their Swedish workplaces. Of the 11 employees featured on AstraZeneca's web pages, one is an immigrant to Sweden, born in Lebanon, and of the 14 featured on Scania's site, one is an immigrant to Sweden, born in Iran, and one a visiting student from Germany. Both these companies could be said to give a fairly good picture of the current Swedish job market. As regards Scania, it should be noted that the German master's degree student is said to be fluent in Swedish. The company's monolingual Swedish culture is not therefore affected by the presence of this German girl.

Though all five companies explicitly stress various societal values, e.g. 'diversity', on their websites, the analysis of the 'success stories' on their career-oriented web 
pages show a division between companies for which diversity mainly relates to global mobility (employees taking on jobs in different countries) on the one hand and others for which diversity relates to the local workplace (employees working in Sweden come from different regions of the world).

\subsection{Workplace Discourse in the 'New Work Order'}

The conditions for professional discourse have been influenced by a series of changes taking place in recent decades. Technological advances have coincided with a globalization of working life and lifelong learning, flexibility, mobility and diversity have come to be key values in the global economy.

The purpose of this section is to sum up research which has analysed workplace discourse in technological organizations and workplaces. I will also speculate about what consequences the 'new work order' might have for the individual employee.

\subsubsection{Technological Advances and Workplace Discourse}

In organizations throughout the world, we find a widespread use of technology and an increased reliance on the internet for internal and external communication. Text and speech in traditional forms are intertwined with computer-mediated communication, phone calls and video-conferencing in a way that gives presence and simultaneity a new significance. Distance communication is increasing and reducing the importance of being at a certain place at a certain time. The extended access to computers and advanced technology at work have also led to an increased role for multimodality; words and visual elements are interwoven in most texts and professional talks are often given with both textual and visual support.

Every strand of workplace communication has, in one way or the other, been transformed by technology. Writing at work has been affected by technology, and new written genres and new writing processes have developed as a result of the use of fax, email and the World Wide Web ${ }^{9}$. The use of speech in the workplace has also been influenced by the technological advances ${ }^{10}$, and phone calls and videoconferencing are intertwined with computer-mediated interaction leading to new interpretations of presence and simultaneity at work.

Multimodality is not a new phenomenon ${ }^{11}$, but technological developments in recent decades have prompted growing interest in multimodality as a phenomenon, its function and impact on discourse. Text, speech, graphs, recorded sound and movies are interwoven in today's communication in a way which was not previously possible ${ }^{12}$.

The technological advances have also given rise to different types of jobs and new workplaces ${ }^{13}$. Call centres and help desks may function in remote parts of the world, blurring the traditional concept of workplace and organizational connection. New genres and new communicative processes have developed at these workplaces ${ }^{14}$. 
Though these studies offer glimpses of the interlacement of discourse and technology at work and sketch methods to enable analysis, the next step should be to analyse the consequences for the individual employees of the various changes in the conditions for work which are found in the new, global economy.

\subsubsection{The Individual Employee in the 'New Work Order'}

The term 'new work order' has sometimes been used to refer to the redistribution of roles, skills and knowledge in the modern global economy, (cf. Gee et al., 1996; Hull, 1997). The modern organization constantly needs to modify products and customize them in order to survive in the over-competitive global marketplace. For the modern organization, a decentralized and flexible structure with temporary and rapidly changing networks is more valuable than stability and long-lasting structures. Organizations have fewer levels, which means that there are fewer middle managers and less administrative staff, while at the same time the unskilled jobs/tasks have disappeared. In terms of division of labour, this development has meant a downward shift of responsibility to the individual employees. The organizations must find means to empower their workforces, for instance core visions and cultures should be shared by managers and workers alike. For the employees, this new situation means different and higher demands on literacy and communicative skills.

Organizations competing on the global market need to be flexible and able to learn also in relation to discourse. Compared to earlier organizations, the modern one is characterized by more meetings, more documentation and also an increased need for training and advice. The 'ideal' employee is a flexible person who is continuously learning as she/he moves within the organization and between organizations, thus taking on new jobs and performing new tasks. Instead of unskilled workers performing routine tasks, organizations need staff who can act independently, plan their own work and take responsibility for their role in production. They should be able to communicate more or less directly with the top levels within the organization. The new work order is thus demanding greater flexibility and responsibility from individual employees. Organizational structures based on workforce mobility and workplace diversity also make higher demands of the language knowledge and cultural openness of the individual workers.

\subsection{Topics for Future Research}

As has been discussed in this chapter, professional discourse has been influenced by a series of changes because of new technology and globalization. The 'new work order' has had effects on working life in general and on the working conditions for individuals employed in or networking with large or small organizations. A goal for future research into discourse in organizations and workplaces is to analyse the various 'new' problem areas as well as to try to sketch how difficulties could be overcome. In this last section I dwell on a few topics which relate to the various issues discussed earlier in this chapter. 
Organizations in the 'new work order' are described as having fewer levels. Hierarchies are reduced and the structural connection between organization and workplace is blurred. Nevertheless we can assume that organizations will survive as uniform entities. One topic for future research would be to explore the new roles of discourse in the construction of an 'organizational self' in the global economy and for the maintenance of a social order in blurred contextual frames. How are large organizations constructed and maintained by means of the internet and distance-communication? What role do different types of discourse play for the formation of a uniform organization?

An important set of topics relate to the employees' group affiliations in the new work order. Earlier studies have found that humour, storytelling and teasing are essential elements in the discourse of a close-knit workplace. In order to be a full member of a working group, you must, for instance, know what jokes are socially accepted and whom you can tease and in what way. A topic for future research is to analyse if similar socializing patterns are also established in working groups held together by means of distance-communication. What roles, if any, do humour and storytelling play in such communication? Do these elements play a role also in organizations which use English - or another language - as a lingua franca? Do employees who sit at home working on their computers feel integrated into a workplace group?

Fewer levels and reduced hierarchies result in vagueness and tension for individual employees. The need for workforce flexibility also leads to a form of growing de-professionalization. Role relationships and identities have to be renegotiated and new ones formed over and over again. For the individual this situation is likely to create uncertainty and stress. A topic for future research would be to analyse the role of discourse in the (re)negotiation of job identities and job relationships within flat organizations.

Another topic which would be worth looking into relates to the role of discourse for bottom-up influence. The physical distance between one workplace and another is a reality in large, global organizations, which indeed means that both top-down and bottom-up communication have to be less direct. A research question is whether this physical distance hinders bottom-up influence on the organization. By what type of discourse is democracy established - and hindered - in the "new work order'? How does the new worker get his/her voice through to the top management level? How does top management try to steer the shop floor workers? What role does language difference play for patterns of influence?

The new work order is also characterized by extended networking. Large companies merge, but there is a framework of small group collaboration in the big concerns. An interesting topic related to power and dominance would be to analyse if and how small network partners manage to influence the decisions of large organizations?

In the global economy, organizations have to strike a balance between local and global concerns as well as between economic concerns and social-societal values in order to be competitive and trustworthy. The challenge for large organizations is to find a balance in policy and practice between these various considerations. Important topics for future research would be to analyse how discourse in organizations 
and workplaces reflect this balance. How is diversity constructed in workplace discourse? Who is marginalized and who is made central through workplace discourse? What societal values are expressed in official documents and more informal discourse within organizations?

\section{Notes}

1 In this chapter, I sometimes use 'text' for both spoken and written discourse.

2 A number of studies on discourse in organizations and workplaces have been carried out at Uppsala University in Sweden. For presentations of the major ones, see Gunnarsson (2009a)

3 Interview with a retail display designer working for IKEA (Språket, SR1, 6 September 2005).

4 Compare, for instance Nickerson (2000).

5 A full description of this study is presented in Kankaanranta (2005b).

6 In the Uppsala research project entitled The Communicative Situation of Immigrants at Swedish Workplaces, the initial step comprised semi-structured interviews with female and male immigrants working in a hospital and a Swedish major company.

7 A number of studies on workplace discourse have been carried out in New Zealand within the Wellington Language in the Workplace Project. Among the large number of publications emanating from this group, I here wish to mention: Holmes et al. (1999), Holmes (2000), Holmes and Stubbe (2003), Marra and Holmes (2004), Holmes (2005).

8 Preliminary results from this research project, entitled The Communicative Situation of Immigrants at Swedish Workplaces, are discussed in Andersson and Nelson (2005), Nelson and Andersson (2005), Andersson (2006) and Nelson (2007). A full presentation of the case studies of second language speakers at a Swedish hospital is found in Andersson (2009), which is her Ph.D. thesis. Nelson's study of interaction at a Swedish major company will be presented in full in her forthcoming Ph.D. thesis from Uppsala University.

9 See, for instance, Louhiala-Salminen (1995), Bargiela-Chiappini and Nickerson (1999), Nickerson (2000), Luzon (2002), Kankaanranta (2005b).

10 See Pan et al. (2002).

11 Cf. John Swales' analysis of a university building (1998).

12 See, for instance, Lemke (1999), LeVine and Scollon (2004), Norris and Jones (2005), Karlsson (2006 and 2007).

13 Interesting analyses are found in Sarangi and Roberts, (eds) (1999).

14 See, for instance, Culver et al. (1997), Landqvist (2001), Qvortrup (2002), Kong (2002), Oliveira (2004), Silva et al. (2004), Wiberg (2005).

\section{References}

Andersson, H. (2006), Interkulturell kommunikation inom sjukvården. Den kommunikativa situationen för invandrare på svenska arbetsplatser 1. Intervjuer. (TeFa $\mathrm{nr} 45)$. Uppsala. 
Andersson H. (2009), Interkulturell kommunikation på ett svenskt sjukhus. Fallstudier av andraspråkstalare $i$ arbetslivet [Intercultural Communication at a Swedish Hospital. Case Studies of Second Language Speakers in a Workplace]. (Skrifter utgivna av Institutionen för nordiska språk vid Uppsala universitet 77.) Uppsala: Swedish Science Press.

Andersson, H. and Nelson, M. (2005), 'Communication at work. The communicative situation of immigrants at Swedish workplaces', in B.-L. Gunnarsson (ed.), The Immigrant and the Workplace. (TeFa nr 41) Uppsala, pp. 27-46.

Bargiela-Chiappini, F. and Nickerson, C. (eds) (1999), Writing Business: Genres, Media and Discourses. New York: Longman.

Börestam, U. (2005), 'Culture and culture again. An inter-Nordic merger in the banking sector', in B.-L. Gunnarsson (ed.), Communication in the Workplace. (TeFa $\mathrm{nr} 42$ ), Uppsala, 60-77.

Culver, J. D., Gerr, F. and Frumkin, H. (1997), 'Medical information on the internet: A study of an electronic bulletin board', Journal of General Internal Medicine, 12, (8), 466-470.

Fant, L. (1992), 'Scandinavians and Spaniards in negotiation', in A. Sjögren and L. Janson (eds), Culture and Management. In the Field of Ethnology and Business Administration. Botkyrka, pp. 125-153.

Gee, J., Hull, G. and Lankshear, C. (1996), The New Work Order. London: Allen and Unwin.

Gunnarsson, B.-L. (1997), 'The writing process from a sociolinguistic viewpoint', Written Communication, 14, (2), 139-188.

Gunnarsson, B.-L. (2001), 'Swedish tomorrow - a product of the linguistic dominance of English?', in S. Boyd and L. Huss (eds), Managing Multilingualism in a European Nation-state. Challenges for Swedish. Clevedon: Multilingual Matters Ltd, pp. 51-69.

Gunnarsson, B.-L. (2004a), 'The multilayered structure of enterprise discourse', Information Design Journal + Document Design, 12, (1), 36-48.

Gunnarsson, B.-L. (2004b), 'Orders and disorders of enterprise discourse', in C. Gouveia, C. Silvestre, and L. Azuaga (eds), Discourse, Communication and the Enterprise. Linguistic Perspectives, University of Lisbon Centre for English Studies, Lissabon, pp. 17-39.

Gunnarsson, B.-L. (2005), 'The immigrant and the workplace: The societal frame', in B.-L. Gunnarsson (ed.), The Immigrant and the Workplace. (TeFa $\mathrm{nr} 41$ ). Uppsala, pp. 13-17.

Gunnarsson, B.-L. (2006), 'Swedish companies and their multilingual practices', in J. C. Palmer-Silveira, M. F. Ruiz-Garrido and I. Fortanet-Gómez (eds), International and Intercultural Business Communication. Theory, Research and Teaching. Bern: Peter Lang, pp. 243-263.

Gunnarsson, B.-L. (2009a), Professional Discourse. (Continuum Discourse Series.) London: Continuum.

Gunnarsson, B.-L. (2009b), 'Multilingualism within transnational companies. An analysis of company policy and practice in a diversity perspective', in H. Kelly-Holmes and G. Mautner (eds), Language and the Market. Basingstoke and New York: PalgraveMacmillan.

Gunnarsson, B.-L. and Jämtelid, K. (1999), 'Översättning och parallellskrivning flerspråkig textproduktion inom ett internationellt storföretag', in Svenskans beskrioning 23. Lund: Lund University Press, pp. 134-142. 
Holmes, J. (2000), 'Politeness, power and provocation: How humour functions in the workplace', Discourse Studies, 2, (2), 159-185.

Holmes, J. (2005), 'Story-telling at work: A complex discursive resource for integrating personal, professional and social identities', Discourse Studies, 7, (6), pp. 671-700.

Holmes, J., Stubbe, M. and Vine, B. (1999), 'Constructing professional identity: "Doing power" in policy units', in S. Sarangi and C. Roberts (eds), Talk, Work and Institutional Order. Discourse in Medical, Mediation and Management Settings. Berlin and New York: Mouton de Gruyter, pp. 351-385.

Holmes, J. and Stubbe, M. (2003), Power and Politeness in the Workplace. A Sociolinguistic Study of Talk at Work. London: Longman.

Hull, G. (ed.) (1997), Changing Work, Changing Workers: Critical Perspective on Language , Literacy and Skills. Albany: State University of New York Press.

Isaksson, M. (2005), 'Ethos and pathos representations in mission statements: Identifying virtues and emotions in an emerging business genre', in A. Trosborg and P. E. Flyvholm Jørgensen (eds), Business Discourse. Texts and Contexts, Bern, Berlin, Frankfurt am Main: Peter Lang, pp. 111-138.

Johansson, C. (2003), Visioner och verkligheter. Kommunikationen om företagets strategier. Department of Information Sciences, Uppsala University, Uppsala.

Jämtelid, K. (2001), 'Multilingual text production at an international company', in F. Mayer (ed.), Language for Special Purposes: Perspectives for the New Millenium. Volume 2. Tübingen: Gunter Narr Verlag, pp. 797-805.

Jämtelid, K. (2002), Texter och skrivande i en internationaliserad affärsvärld. Flerspråkig textproduktion vid ett svenskt storföretag. Stockholm: Almqvist \& Wiksell International.

Kankaanranta, A. (2005a), 'English as a corporate language: Company-internal e-mail messages written by Finns and Swedes', in B.-L. Gunnarsson (ed.), Communication in the Workplace. (TeFa nr 42), Uppsala, pp. 42-59.

Kankaanranta, A. (2005b), 'Hej Seppo, could you pls comment on this!' Internal Email Communication in Lingua Franca English in a Multinational Company. Centre for Applied Language Studies, University of Jyväskylä, Jyväskylä.

Karlsson, A. M. (2006), En arbetsdag $i$ skriftsamhället. Ett etnografiskt perspektiv på skrifanvändning $i$ vanliga yrken. (Småskrift utgiven av Språkrådet). Stockholm: Norstedts akademiska förlag.

Karlsson, A.-M. (2007), 'Text, situation, praktik. Om ramar och resurser för tolkning av texter i arbetsrelaterade skrifthändelser', in B.-L. Gunnarsson and A.-M. Karlsson (eds), Ett vidgad textbegrepp. (TeFa nr 46). Uppsala, 27-40.

Kong, K. C. C. (2002), 'Managing the ambiguous and conflicting identities of "upline" and "downline" in a network marketing firm', Discourse Studies, 4, (1), 49-74.

Landqvist, H. (2001), Råd och ruelse. Moral och samtalsstrategier i Giftinformations centralens telefonrådgivning. (Skrifter utgivna av Institutionen för nordiska språk 55.) Uppsala.

Lemke, J. L. (1999), 'Discourse and organizational dynamics: Website communication and institutional change', Discourse E Society, 10 (1), 21-47.

LeVine, P. and Scollon, R. (ed.) (2004), Discourse and Technology: Multimodal Discourse Analysis. Washington, DC: Georgetown University Press. 
Linde, C. (1999), 'The transformation of narrative syntax into institutional memory', Narrative Inquiry, 9, (1), 139-174.

Louhiala-Salminen, L. (1995), 'Drop Me a Fax, Will You?': A Study of Written Business Communication. (Reports from the Department of English 10). Jyväskylä: University of Jyvaskyla, 1-115.

Luzon, M. M. J. (2002), 'A genre analysis of corporate home pages', LSP and Professional Communication, 2 (1), 41-56.

Marra, M. and Holmes, J. (2004), 'Affiliation workplace narratives and business reports: Issues of definition', Text, 24, (1), 59-78.

Nelson, M. (2007), 'Professionella och socialiserande kommunikativa aktiviteter. Andraspråkstalande kvinnor och män i arbete', in B.-L. Gunnarsson, S. Entzenberger and M. Ohlsson (eds), Språk och kön i nutida och historiskt perspektiv. (Skrifter utgivna av Institutionen för nordiska språk 71.) Uppsala, 287-298.

Nelson, M. and Andersson, H. (2005), 'Andraspråkstalare i arbetslivet. Data från intervjuer och fallstudier', in U. Börestam and B.-L. Gunnarsson (eds), Språk och kultur i det multietniska Sverige (TeFa nr 44), Uppsala, pp. 84-97.

Nickerson, C. (2000), Playing the Corporate Language Game. An Investigation of the Genres and Discourse Strategies in English Used by Dutch Writers Working in Multinational Corporations. Amsterdam: Rodopi.

Norris, S. and Jones, R. H. (2005), Discourse in Action. Introducing mediated discourse analysis. London and New York: Routledge.

Oliveira, M. C. L. (2004), 'Language, technology and modernity: A study of interaction in a Call Center', in C. Gouveia, C. Silvestre, and L. Azuaga (eds), Discourse, Communication and the Enterprise. Linguistic Perspectives, University of Lisbon Centre for English Studies, Lissabon, pp. 65-78.

Pan, Y., Scollon, S. W. and Scollon, R. (2002), Professional Communication in International Settings. Malden, MA and Oxford: Blackwell Publishers.

Peters, T. J. and Waterman, R. H. (1982), In Search of Excellence: Lessons from America's Best-Run Companies. New York: Harper and Row.

Qvortrup, L. (2002), The Hypercomplex Society. New York: Peter Lang.

Sarangi, S. and Roberts, C. (eds) (1999), Talk, Work and Institutional Order. Discourse in Medical, Mediation and Management Settings. Berlin and New York: Mouton de Gruyter.

Silva, J. R. G., Oliveira, M. C. L. and Zaltzman, C. (2004), 'Communication with customers and the quality of public services. The case of a Brazilian company', in Gouveia, C., Silvestre, C. and L.Azuaga (eds), Discourse, Communication and the Enterprise. Linguistic Perspectives, University of Lisbon Centre for English Studies, Lissabon, pp. 43-63.

Swales. J. M. (1998), Other Floors, Other Voices: A Textography of a Small University Building. Mahwah, NJ: Erlbaum.

Swales, J. M. and Rogers P. S. (1995), 'Discourse and the Projection of Corporate Culture: The Mission Statement'. Discourse E' Society, 6, (2), 223-242.

Wiberg, M. (ed.) (2005), The Interaction Society. Practice, Theories and Supportive Technologies. Hershey, London, Melbourne, Singapore: Information Science Publishing. 